\title{
側頭骨外顔面神経の神経線維局在に関する実験的研究
}

\author{
愛媛大学医学部耳鼻咽喉科学教室 (主任：柳原尚明教授) \\ 浅 井 真 紀

\section{FUNICULAR STRUCTURE AND NERVE FIBER TOPOGRAPHY IN THE EXTRATEMPORAL FACIAL NERVE OF THE GUINEA PIG}

MASANORI ASAI, M.D.

Department of Otolaryngology, School of Medicine, Ehime University, Ehime

The intratemporal portion of the facial nerve has a single bundle, while the extratemporal portion has multiple funiculi. In the guinea pig, the funiculi repeatedly divide and fuse between the stylomastoid foramen and the origin of the inferior labial branch. It remains unknown whether the nerve fibers in each funiculus are topographically organized or not. In this paper, the topographic organization of nerve fibers in a funiculus was clarified in the extratemporal facial nerve trunk of the guinea pig using an anterograde nerve degeneration technique.

The author developed a technique in which one funiculus is cut selectively proximal to the origin of the cervical branch or peripheral to the origin of the inferior labial branch using microscissors under an operation microscope. Four to six days after sectioning, the main trunk just peripheral to the sectioned site was examined with toluidine blue staining to confirm that the resultant degeneration was limited to only one funiculus. Then all six main peripheral branches were sectioned and the distribution of degenerated nerve fibers in each branch was examined with toluidine blue staining.

In six out of eleven nerves sectioned just proximal to the origin of the cervical branch, the degenerated nerve fibers were localized in one main peripheral branch. In the remaining five nerves, the degenerated nerve fibers spread into two or three main peripheral branches. In all nerves sectioned just peripheral to the origin of the inferior labial branch, the degenerated nerve fibers were localized in only one main peripheral branch, even though they distributed to several funiculi in the same branch.

These results indicate that topographic organization of the nerve fibers in a funiculus is as yet incomplete in the portion proximal to the cervical branch, but is roughly complete in the portion peripheral to the inferior labial branch. Funicular division and fusion in the extratemporal facial nerve trunk is thought to be a specific structure which favors organization of the nerve fibers topographically for proper innervation of the mimetic muscle.

Key words : 顔面神経の解剖, 側頭骨外顔面神経, 神経束構造,

A $96-1227-91510$

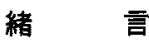

顔面神経は側頭骨内では単一神経束で，荎乳突孔の
やや中枢側から神経束が形成され始め, 側頭骨外で多 神経束になるという解剖学的特徴を持っているが，な 
ぜこのように末梢において神経束構造が変化するかに ついては十分に解明されていない. 神経枝切断後の逆 行性変性や HRP などによる研究により脳幹の顔面神 経核においては顔面の表情筋を支配する神経核が支配 領域別に局在していることが明らかにされているが， 側頭骨内顔面神経や側頭骨外顔面神経幹において神経 線維の局在があるかどうかについては，多くの研究に もかかわらずいまだに結論は得られていない.

本研究ではモルモットを用いて側頭骨外顔面神経幹 において 1 本の神経束を選択的に切断する手技を開発 し，末梢の神経変性を組織学的に観察することにより 顔面神経の神経束内線維の局在性について新しい知見 を得たので報告し, 神経束内の線維分布についても考 察する。

\section{実験}

1. 実験の目的と原理

図 1 にモルモットの側頭骨外顔面神経の主要分枝を 示す。主な分枝は 6 本あり, 茎乳突孔を出た後, 最初 に後耳介枝を, 次いで, 頸枝, 下口唇枝, 上口唇枝, 煩骨眼輪筋枝，前耳介枝の順に分枝し，それぞれの領 域の顔面筋を支配する，頸枝と下口唇枝はほぼ同じレ ベルで，頸枝は内側から，下口唇枝は外側から分枝す る.

本実験の目的は側頭骨外において選択的に 1 本の神 経束を切断した後に起こる各末梢分枝内での Waller 変性を観察することにより，神経束内における神経線 維の局在の有無を検討することにある．もし 1 本の神 経束内に支配領域に応じた神経線維が局在していると すると，その神経束が選択的に切断された場合，末梢 の一つの分枝内のごく限られた神経束にのみ変性線維 が認められるはずである。もしそのような局在性がな ければ，複数の分枝に一様に变性線維が認められるは ずである。

すでに報告したように，モルモットはヒトと同様に 側頭骨内では単一神経束であるが，茎乳突孔よりやゃ 中枢側で神経束が形成され始め, 側頭骨外に出ると神 経束の数が急激に増え，末梢に進むにしたがって神経 束は細く，数も多くなる．そして頸枝分岐部までの間 で神経束は複雑に分岐・吻合を繰り返し，下口唇枝分 岐部より末梢になるとほぼ一定の方向に走行する ${ }^{11}$. 以上の所見を踏まえて，本実験では頸枝分岐部の中枢 側と下口唇枝分岐部の末梢側の 2 力所で，1 本の神経 束を選択的に切断し，末梢分枝の神経束内における変

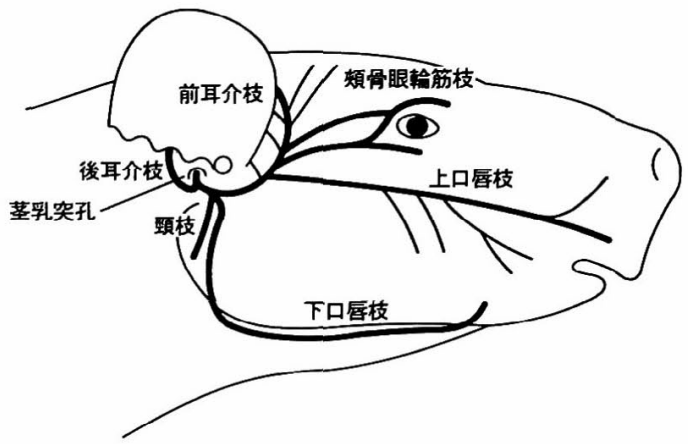

図 1 モルモット側頭骨外顔面神経の主要分枝
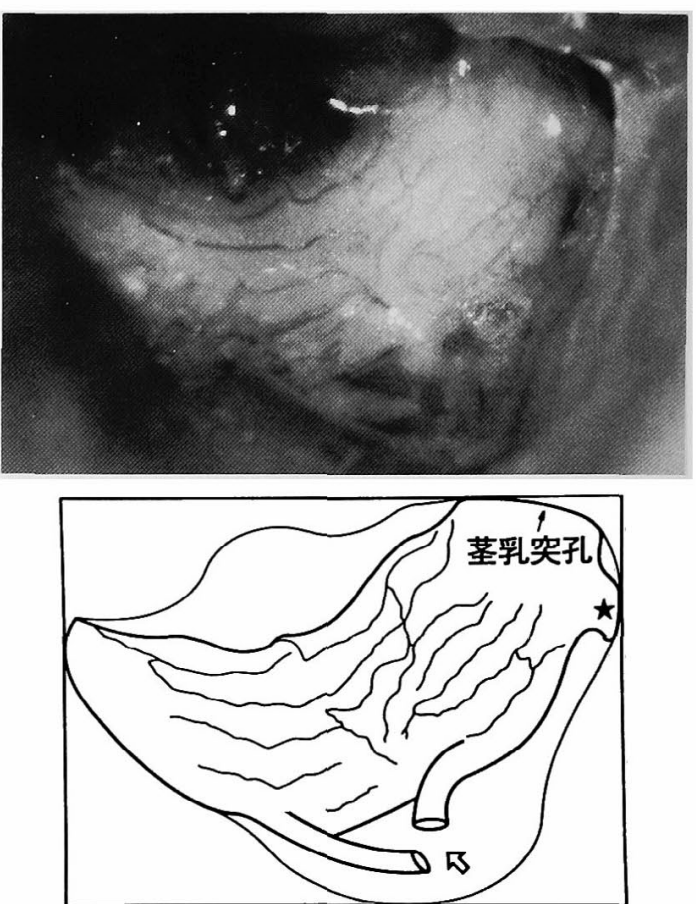

図 2 神経束切断部 （左側頭骨外顔面神経において,下口唇枝 分岐部より末梢で最下方の神経束を切断 したところ：矢印は切断された神経束断 端, Ł：下口唇枝)

性線維の分布の差異を検討した。

2. 選択的神経束切断の方法

実験には体重 400～600g のモルモットを用いた。ま ず, ペントバルビタール $(30 \mathrm{mg} / \mathrm{kg})$ の腹腔内投与で 全身麻酔後, 手術局所に $1 \%$ リドカインの浸潤麻酔を 行った. 耳後部に皮膚切開を加え, 手術用顕微鏡下に 側頭骨外顔面神経を剖出した．視野を25倍に拡大する 


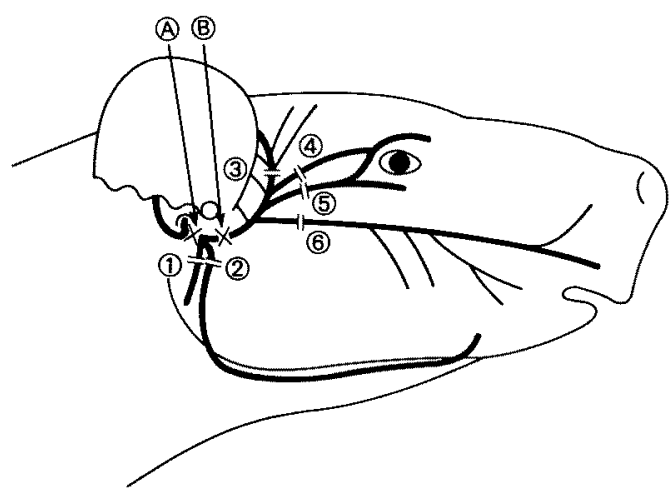

図3神経採取部位

(B)(B)は神経束切断部, (1)～(6)は末梢分枝 採取部)

と薄い神経鞘を通して神経束が透見できるので, 神経 上膜のみを精密ピンセット（INNOXNo.5) を用いて 注意深く除去した，個々の神経束の走行が識別できる ようになれば,目的とする神経束の神経周膜を把持し， 白内障手術用のバーナス剪刀を用いて選択的に 1 本の 神経束のみを切断除去した(図 2)，4〜6日目に切断 部を含む側頭骨外本幹を採取し，トルイジンブルー染 色を行い，1本の神経束が選択的に切断できているか どうかを組織学的に確認した。

\section{3. 末梢分枝の組織学的検討}

選択的神経束切断後，4〜6日目に図 3 に示す部位 で切断部および末梢の各分枝を採取し，3\%グルター ルアルデヒドにて固定後， $2 \%$ 四酸化オスミウムで後 固定した．次いで，酢酸ウランでプロック染色を行い, エタノール系列で脱水, エポンに包埋した. PorterBlum 型ミクロトームを用いて $0.5 \mu \mathrm{m}$ の横断切片を 作製し, $0.5 \%$ トイジンブルー染色を行い, 光学顥微 鏡下に変性神経線維の分布を検討した。トルイジンブ ルー染色では正常の有髄神経線維は艏䩗がリング状に 認められるのに対し, 変性線維はブルーの塊状または 有髄神経線維密度の減少として認められる。

\section{4. 対 象}

神経束切断のレベルにより頸枝分䁌部より $1 \mathrm{~mm}$ 中 枢部で切断したものを A 群とし，下口唇枝分貱部より $2 \mathrm{~mm}$ 末梢部で切断したものをB群とした。さらにそれ ぞれのレベルで, 神経表層の 3 つの異なる神経束, す なわ方上方, 中央, 下方の識別可能な 1 本の神経束を 切断した，以下，それぞれを $\mathrm{A}$ (上方) 群，A（中央） 群, A (下方) 群, B (上方) 群, B (中央) 群, B (下方) 群と記載する。
表 1 対象症例

\begin{tabular}{|c|c|c|c|}
\hline & \multirow[b]{2}{*}{ 例数 } & \multicolumn{2}{|c|}{ 単一神経束切断例 } \\
\hline & & $\begin{array}{l}\text { 手術用 } \\
\text { 顕微鏡下 }\end{array}$ & $\begin{array}{l}\text { 組織学的 } \\
\text { (六内は } \\
\text { 成 功率 }\end{array}$ \\
\hline 切断部A (上方) & 8 & 8 & $5(63 \%)$ \\
\hline A (中央) & 8 & 6 & $4(50 \%)$ \\
\hline$A$ (下方) & 8 & 4 & $2(25 \%)$ \\
\hline 切断部 B (上方) & 12 & 11 & $6(50 \%)$ \\
\hline B (中央) & 12 & 6 & $4(33 \%)$ \\
\hline B (下方) & 12 & 12 & $6(50 \%)$ \\
\hline
\end{tabular}

実験にはA群ては各 4 匹，B群では各 6 匹，計30匹 の両側顔面神経を使用した．神経束を切断すると，手 術用影微鏡下に神経束の断端が確認できる。顕微鏡下 に単一の神経束が切断できたと思われたものは47例 でそれらの例では神経束切断部のすぐ末梢側をトル イジンブルーで染色し，神経の変性を観察した。その 結果，47例のうち27例で 1 本の神経束内に変性線維が 見られ，選択的に単一神経束が切断されていたが，残 りの例では複数の神経束に変性線維が認められ，これ らの例は検討対象から除外した，表 1 に検討対象とな った例数を示す.A群では24例中11例で選択的切断に 成功した。その内訳は $\mathrm{A}$ (上方) 群が5例， A (中央) 群が 4 例で，A（下方）群が 2 例であった。. B群にお いては36例中16例で選択的切断に成功した．その内訳 は B (上方) 群が 6 例, B (中央) 群が 4 例で, B (下 方）群が 6 例であった。

\section{結 果}

1. 頸枝分岐部より中枢で切断した群；A群

A（上方）群においては 5 例中 3 例で 1 つの末梢分 枝にのみ変性線維が局在しており, 残り2例では複数 の末梢分枝に変性線維が散在していた。図 4 に局在性 を示した 1 例を示す.図 4 上段は切断部よりわずかに 末梢の横断切片像である。選択的切断により1本の神 経束内の神経線維にのみ変性が琶められる，図4下段 は末梢の前耳介枝の横断像であり，5本の神経束内に 変性線維が散在しているのがわかる. しかし, 他の末 梢分枝には変性線維は認められなかった。残りの2 例 では上口長枝内にのみ変性線維が局在し, 変性線維は 3 〜 本の神経束に分布していた。

図 5 に非局在性を示した 1 例を示す。末梢において は下口唇枝と前耳介枝の両枝に変性線維が認められ 

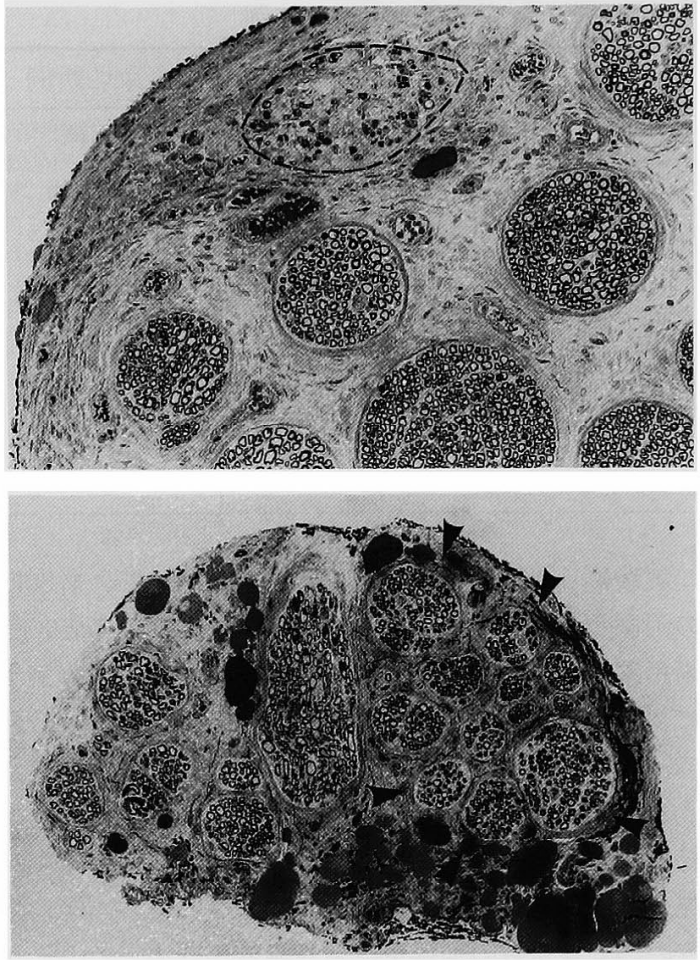

図 4 A（上方）群の局在例

上段：切断部（図 3 の(A) 横断組織像 変性線維は 1 本の神経束内に限局（円 内). $(\times 50)$

下段：前耳介枝（図 3 の(3)）横断組織像 変性線維は 5 本の神経束内に散在（矢 印). ( $\times 40)$

た.もう 1 例の非局在例では前耳介枝と上口唇枝, 下 口唇枝内に変性線維は散在していた。

中央部の神経束を切断した $\mathrm{A}$ (中央) 群においては 4 例中 2 例では上口唇枝のみに变性線維が局在してい たが, 残りの 2 例では前耳介枝と上口唇枝に変性線維 が散在していた。

A（下方）群では十分な手術体位が取れず，さらに は頸枝分岐部より中枢では神経束同士が密にくっつい ており， 2 例でのみ 1 本の神経束の選択的切断が可能 であった，その内，1例では上口唇枝にのみ変性線維 が局在しており，他の 1 例では頸枝と上口唇枝に変性 線維が散在していた。

以上より, 頸枝分岐部より中枢で 1 本の神経束を切 断した場合には11例中 6 例で局在性が認められた.す なわち, 変性線維が一つの末梢分枝のみに限局してい た. 残りの 5 例では局在性は認められず, 複数の末梢
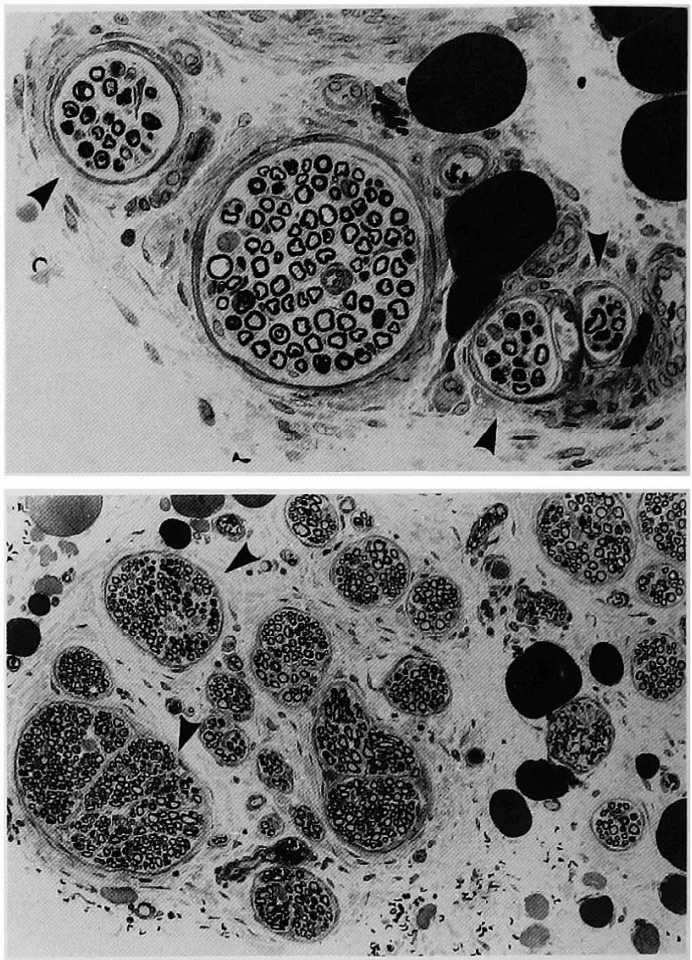

図 5 A (上方) 群の非局在例

上段：下口唇枝（図 3 の(2) 横断組織像 変性線維は 3 本の神経束内に散在（矢 印). $(\times 100)$

下段：前耳介枝（図 3 の(3) 横断組織像 変性線維は 2 本の神経束内に存在（矢 印). $(\times 50)$

分枝に散在していた。 そして，いずれの場合にも末梢 分枝内では変性線維は $3 \sim 5$ 本の神経束に分布してい た.

2. 下口唇枝分岐部より末梢で切断した群; B 群

B（上方）群においては 6 例全例で, 顔面の上半分 を支配する前耳介枝, 頉骨眼輪筋枝には変性は認めら れず，上口唇枝にのみ変性線維が局在していた。 図 6 にその 1 例を示す. 変性線維は上口唇枝内では上方に 位置する 3 つの神経束に分布していた。

中央の神経束を切断したB（中央）群においても 4 例すべて 1 つの末梢分枝にのみ変性が局在していた. すなわち, 2 例では上口唇枝のみに変性が, 他の 2 例 では煩骨眼輪筋枝にのみ変性が認められた。

B（下方）群においては，6例全例上口唇枝にのみ 変性線維が局在しており, 顔面の上半分を支配する前 耳介枝, 煩骨眼輪筋枝には変性は認められなかった. 

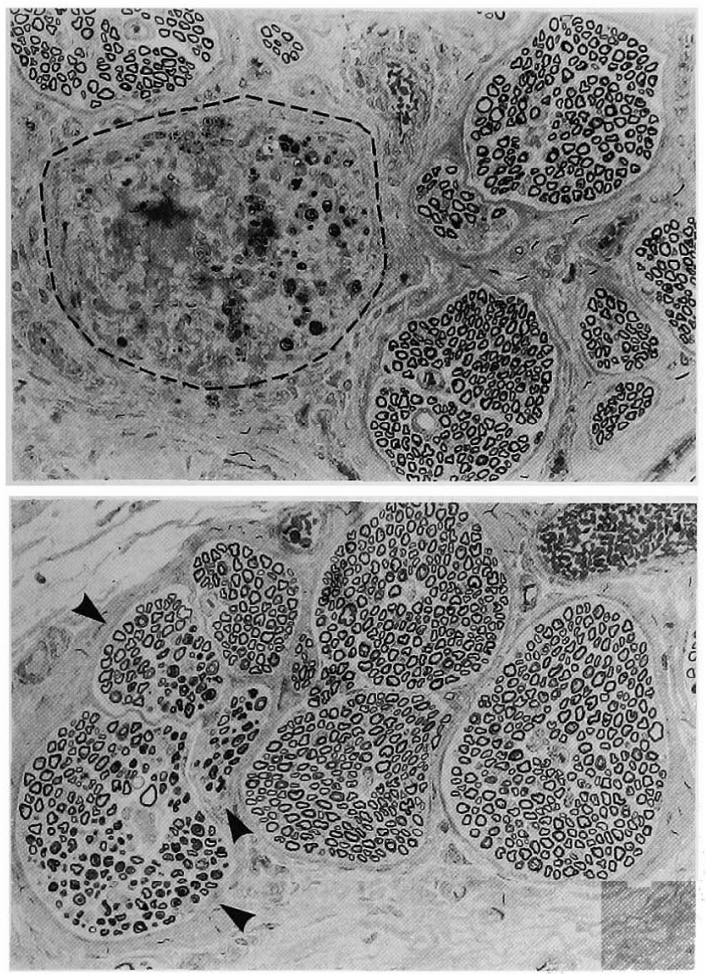

図 6 B (上方) 群の 1 例

上段：切断部（図 3 のB）横断組織像 変性線維は 1 本の神経束内に限局（円 内). $(\times 80)$

下段：上口唇枝（図 3 の(6) 横断組織像 変性線維は 3 本の神経束内に散在（矢 印). $(\times 80)$

以上より，下口唇枝分岐部より末梢で切断した場合 には, 上方, 中央, 下方といった切断部位にかかわら ず全例一つの末梢分枝内にのみ変性線維が認められ, 局在が確認された。しかし, その分枝内では変性線維 は 1 本の神経束には限局しておらず，2〜6本の神経 束内に分布していた.

A群と異なり, 非局在例が認められなかったため, 2 匹ずつ動物を増やし, 各群 6 匹として実験を行った が，やはり B群では非局在例は認められなかった。

\section{考察}

末梢性顔面神経麻疸においては各表情筋の麻舫の程 度が必ずしも同程度でないことや時に一部の表情筋の みに麻㾇を生じることがある゙23).こうした臨床的事実 よりそれぞれの表情筋を支配する顔面神経核あるいは 末梢の顔面神経内の神経線維に局在性が存在するので
はないかと考えられ，これまでに多くの研究が行われ てきた. その結果, 脳幹の顔面神経核においては逆行 性変性による研究でもHRPによる研究でも各表情筋 枝の局在性があることが確認された4)566)。しかし側頭 骨内本幹においては神経線維の局在性はないとする意 見が有力である7) 10).

一方, 側頭骨外顔面神経本幹における神経線維の局 在性に関する研究は少ない. Sunderland ら ${ }^{11)} は$ ヒト 顔面神経の連続横断切片を作成し, 神経束が分岐・吻 合を繰り返すことより神経幹内では局在は存在せず, 本幹から分枝するときに初めて局在が完成するのであ ろうと推測した。また Scoville ${ }^{12)} や S_{\text {Sade }}{ }^{13)}$ は顔面㾏 摹の治療として側頭骨外本幹を部分切断したところ, すべての表情筋が同程度に麻盘したことから，局在性 を否定した。一方, $\mathrm{May}^{14)}$ はネコ顔面神経の垂直部遠 位 $1 / 3$ から末梢での表情筋枝の局在性を検討し, 茎乳突 孔部では後耳介枝は最外側に, 頸枝は後内側に位置す ると報告した. Millesi ${ }^{15)}$ はヒ卜側頭骨外顔面神経の連 続横断切片を検討し, 上行枝を構成する神経束は本幹 の上内側 $1 / 2$ に, 下行枝を構成する神経束は本幹の下外 側 $1 / 2$ に存在すると述べている. Crumley ${ }^{16)}$ は HRP を 用いて, ネコにおける眼輪筋支配枝は茎乳突孔付近に おいて三日月状に外側に存在するとし, 局在説を支持 している。また村上ら ${ }^{17)}$ はモルモットを用いて神経障 害後の病的共同運動の実験を行い, 同じ圧迫時間でも 側頭骨外で圧迫した動物では側頭骨内で圧迫した動物 より病的共同運動が起こりにくかったことより, 神経 束に機能局在が存在する可能性を示唆している. 以上 のように, 局在, 非局在に関しては統一的見解に至っ ていない.

本研究では選択的神経束切断による末梢分枝内の神 経変性を観察することにより神経線維局在の有無を検 討した. 側頭骨内での線維局在を明らかにするために, 従来より神経切断実験が行われているが18)19), 切断部 よりすぐ末梢の横断像を組織学的に検討しておらず, どの程度神経が切断されていたかはっきりしていな い. 側頭骨内では単一神経束構造のため, 神経を鋭的 に半切したつもりでも実際にはそれ以上に変性線維の 範囲が広がっている可能性が大き? ${ }^{14)}$, 実験結果の信 頼性に問題を残している。これに対して, 側頭骨外に おいては多くの神経束が形成されているので, 他の神 経束に障害を及ぽさずに 1 本の神経束のみを選択的に 切断することができるのではないかと考えた. また切 断部のすぐ末梢を組織学的に観察し, 確実に 1 つの神 


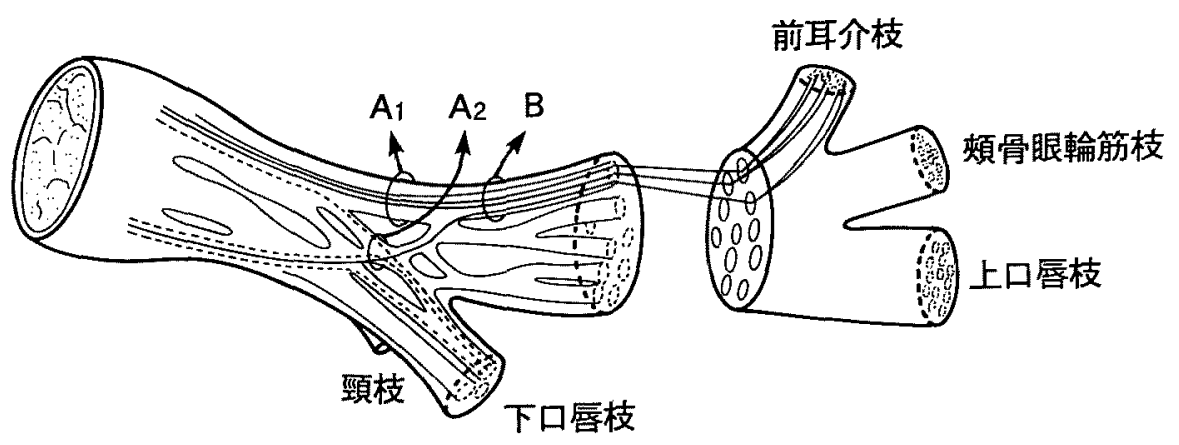

図 7 神経束の分岐・伆合と神経線維局在

分岐部より中枢では局在の完成している神経束 $\left(A_{1}\right)$ と局在 の完成していない神経束 $\left(\mathrm{A}_{2}\right)$ がある。 下口唇枝より末梢で は局在は完成している(B)。しかしより末梢では，その神経 束内に含まれていた神経線維も一つの末梢分岐内に局在して いるが，数本の神経束に散在している。

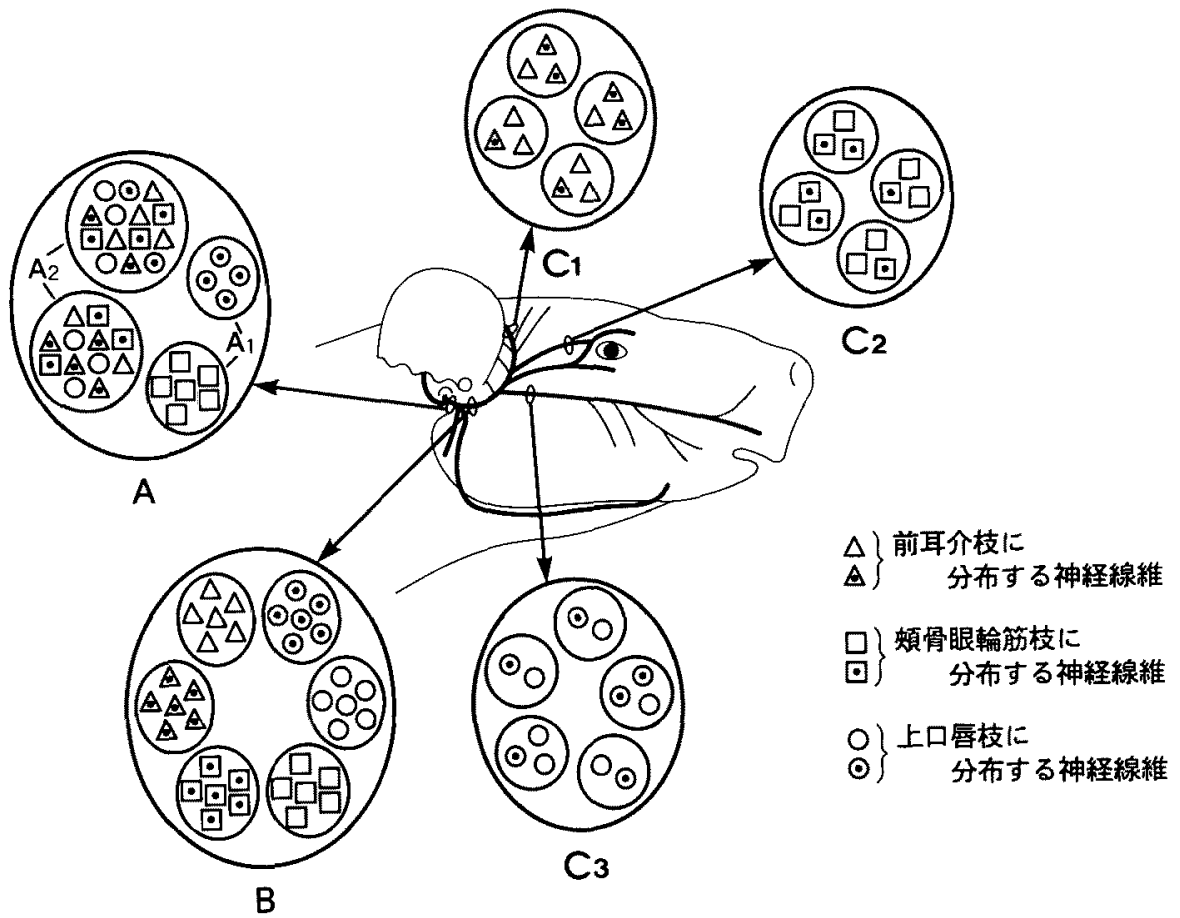

图8 側頭骨外顔面神経の各部位における神経線維局在

$\mathrm{A}$ ：末梢分枝別の局在が完成している神経束 $\left(A_{1}\right)$ とまだ非

局在の神経束 $\left(\mathrm{A}_{2}\right)$ が存在.

B：末梢分枝別に局在が完成。

$\mathrm{C}_{1} \sim \mathrm{C}_{3}$ ：Bで神経束内に局在していた線維は末梢分枝内て は数本の小神経束に分布。

経束が切断できたものについてのみ検討を行った。そ の結果，B群では全例局在性があったのに対し，A群 では局在例と非局在例が認められた. 顔面神経は側頭
骨外に出て下口唇枝を分枝するまでの間に神経束が複 雑に分岐・吻合を繰り返し，末梢になるにつれ神経束 の数が増加する ${ }^{1}$. この所見はすべてのモルモットに 
共通して認められたことから，A群で局在例と非局在 例が認められたのは切断された神経束が異なるため て，動物の個体差によるものではない.したがって， 図 7 にシェーマで示すように, 顔面神経は側頭骨外で 頸枝を分枝するまでは神経束内において支配領域別の 局在性は部分的にしか完成しておらず，下口唇枝を分 枝するまでに局在性が次第に完成することが明らかに された.すなわち，頸枝分岐部より中枢側では $\mathrm{A}_{1}$ のよ うにすでに局在性の完成している神経束と $A_{2}$ のよう にまだ局在性の完成していない神経束がある。その後, 神経束の分岥・吻合により，下口唇枝分岐部より末梢 ではBのように局在性が完成すると考えられる。

一方，下口唇枝分岐部上り末梢の側頭骨外本幹で 1 本の神経束内に存在していた線維がそれより末梢では 1つの分枝内に局在するものの数本の神経束内に分布 しているという事実は末梢に進むにしたがって線維の 局在化が進行するという原則に反する.しかしながら， 複雑な神経束構造とあわせて考えると, 四 8 に示すよ うに顔面神経線維は下口唇枝分岐部までの間で顔面の 各支配領域別に大まかに神経束でまとめられ，その後 神経束がさらに細分され，神経線維も小神経束内に分 散するものと考えられる。すなわち, 顔面神経におい て神経束の分岐と吻合は表情筋の支配領域別に神経線 維を適切に配分するために必要な構造と言える。

Sunderland $ら^{11}$ がヒト側頭骨外顔面神経の横断切 片で報告したのと同様の複雑な神経束構造はモルモッ トでも同じように認められる ${ }^{20)}$.さらに,顔面神経核に おいてもモルモットはヒトと同様に口輪筋周囲を支配 する外側核が優位とされている ${ }^{21222}$.このような解剖 学的類似点から, 今回のモルモットの実験結果はヒト にも当てはまるものと考えられる。しかし，ヒトでは 末梢の表情筋枝同士でも吻合があり，モルモットでは こういった末梢分枝同士の吻合が認められない点から すると，ヒトではより複雑な神経線維の走行があるの かもしれず，興味深いところである.

\section{結語}

モルモットの側頭骨外顔面神経を用いて, 選択的神 経束切断により神経束内の神経線維の局在性の有無を 検討し，以下の結論を得た。

(1) 頸枝分岐部より中枢では神経束内に含まれる神 経線維にはまだ部分的にしか支配領域別の局在性は完 成していない。

(2) 下口唇枝分岐部より末梢においては局在性があ
る.しかし，神経束同士の対応では側頭骨外本幹の 1 つの神経束内に含まれる神経線維は末梢の分枝内では $2 \sim 6 つ$ 神経束に分布する.

(3) 側頭骨外で神経束は複雑に分岐・吻合を繰り返 すことにより, 神経線維の配分を行い, 神経束内に含 まれる神経線維の局在性が完成する。

\section{参考文献}

1）浅井真紀，村上信五，柳原尚明：茎乳突孔付近に扔け る神経東形成について. Otol Jpn 1:70, 1991.

2) Pöllman L: Fazialisparesen. Mschr Ohrenheilkd 71 : 1068-1072, 1937.

3) Neumann $H$ : Die otitischen Fazialisparesen. Wien Med Wschr 56:1233, 1906.

4) Courville $J$ : The nucleus of the facial nerve: the relation between cellular groups and peripheral branches of the nerve. Brain Res 1: 338-354, 1966.

5) Radpour S, Gacek R: Facial nerve nucleus in the cat. Further study. Laryngoscope $90: 685-692$, 1980.

6) Kume $\mathrm{M}$, Uemura $\mathrm{M}$, Matsuda $\mathrm{K}$ et al : Topographical representation of peripheral branches of the facial nerve within the facial nucleus: A HRP study in the cat. Neurosci Lett 8:5-8, 1978.

7) Gacek RP, Radpour S: Fiber orientation of the facial nerve; An experimental study in the cat. Laryngoscope 92:547-556, 1982.

8) Thomander L, Aldskogius H, Grant G: Motor fiber organization in the intratemporal portion of cat and rat facial nerve studied with the horseradish peroxidase technique. Acta Otolaryngol 93: 397-405, 1982.

9）川端五十鈴，石井甲介：側頭骨内顔面神経の神経線維 の配列について。耳鼻臨床 $77: 558-565 ， 1984$.

10）柳原尚明：側頭骨内顔面神経に抢けるTopographic Orientation. 側頭骨内顔面神経麻㾇一病態と治療. 宿 題報告モノグラフ1986, 129-134頁.

11) Sunderland $S$, Cossar DF: The structure of the facial nerve. Anat $\operatorname{Rec} 116: 147-166,1953$.

12) Scoville WB: Partial section of proximal seventh nerve trunk for facial spasm. Surg Gynecol Obstet $101:$ 495-497, 1955.

13) Sade J : Subtotal evulsion of the facial nerve in hemifacial spasm. Acta Otolaryngol $78: 410-417$, 1974. 
14) May M: Anatomy of the facial nerve (spatial orientation of fibers in the temporal bone). Laryngoscope 8:1311-1329, 1973.

15) Millesi $\mathrm{H}$ : Technique of free nerve grafting in the face in Rubin L (ed) Reanimation of the Paralyzed Face. The C.V. Mosby Company, St. Louis, 1977, pp124-135.

16) Crumley RL: Spatial anatomy of facial nerve fibers a preliminary report. Laryngoscope 90:274$280,1980$.

17）村上信五，柳原尚明，丘村 熙：病的共同運動の実験 的研究. Facial N Res Jpn 6: 209-212, 1986 .

18) Harris WD: Topography of the facial nerve. Arch Otolaryngol 88:264-267, 1968.

19) Binns PM : Experimental facial paralysis. Otolaryngol Clin North Am $7: 551-560,1974$.

20）村上信五，柳原尚明：茎乳突孔付近における顔面神経 の神経束構造について. Ear Res Jpn 19: 141-143, 1988.

21) Vraa-Jensen GF : The motor nucleus of the facial nerve in Munksgaard $E$ (ed) With a survey of the efferent innervation of the facial muscles. A nor- mal anatomical study. Saabye \& Christensen, Copenhagen, 1942, pp1-157.

22) Uemura-Sumi $M$, Manabe $Y$, Matsushima $R$ et al: Correlation of the main peripheral branches of the facial nerve with cytoarchitectonic subdivisions of the facial nucleus in the guinea pig. Anat Embryol $174: 161-166,1986$.

稿を終えるに当たって，ご指導とご校閲を睗りました恩 師柳原尚明教授に深甚なる謝意を表します．また本研究に 際し，留切なるご指導をいただきました故 丘村 熙助教 授ならびに村上信五講師に心から感謝いたします。さらに ご協力,ご助言をいただきました愛媛大学医学部第 2 解剖 学教室松田正司講師, 清水大三郎文部技官, 首藤政親文部技 官ならびに教室員各位に深く感謝いたします。

本論文の一部恬第 7 回 (1992年) 国際顔面神経学会, 第 15 回 (1992) 顔面神経研究会にて発表した。本研究は平成 4 年 度の財団法人愛蝯県保健医療財団の援助を受けた。

(1992年12月 7 日受稿 1993 年 3 月 4 日受理)

別刷請求先 干791-02 温泉郡重信町大字志津川 爱姤大学医学部耳鼻咽喉科学教空 浅并真紀 


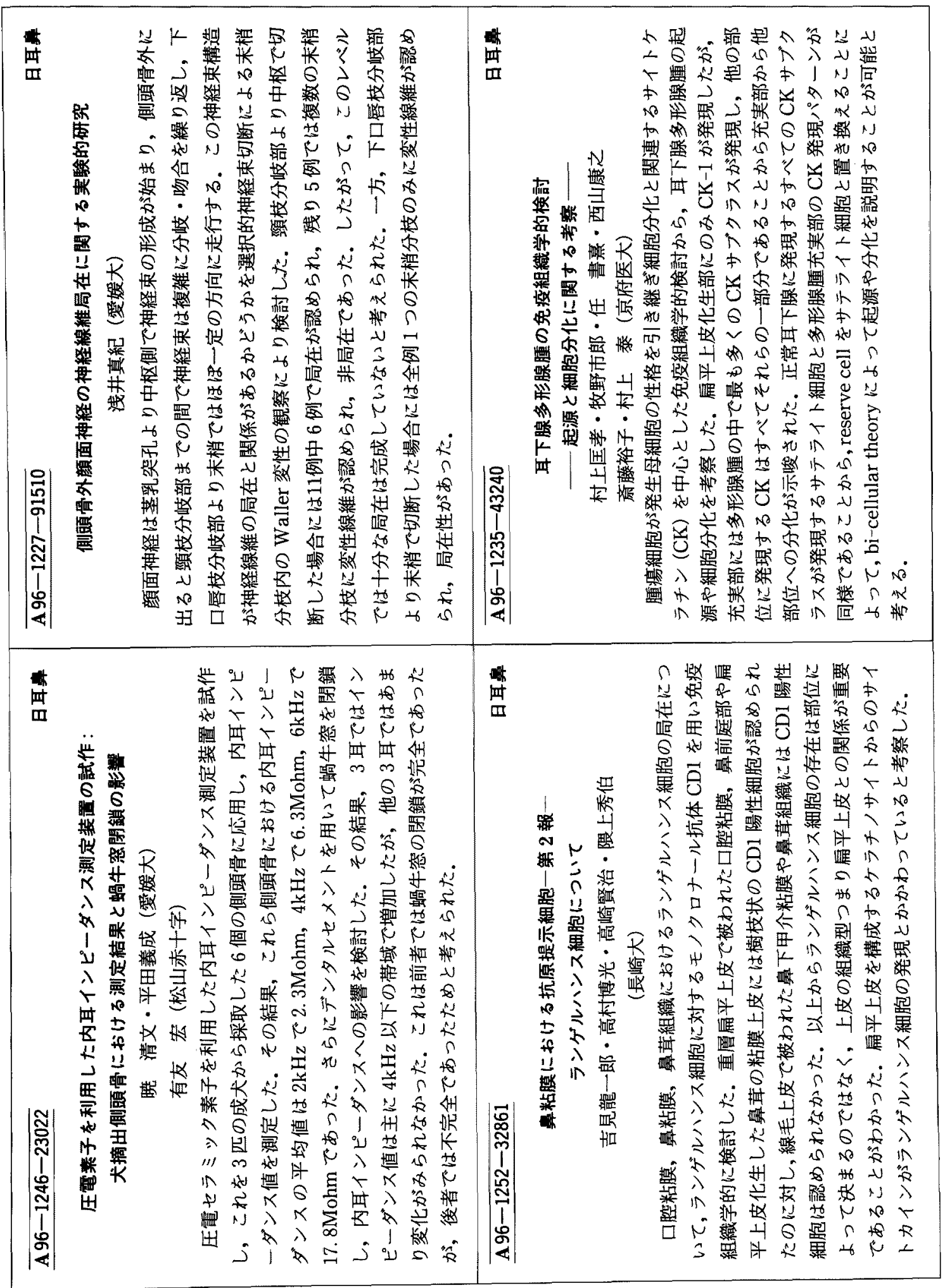

